\title{
Astrotrichia latifolia Benth. Leaf Extracts Lack Antibacterial Activity and are Non-toxic in vitro
}

\author{
Lindiwe Nomathemba Mpala', Getmore Rumbudzai Chikowe ${ }^{2}$, Ian Edwin Cock ${ }^{1,2, *}$ \\ 'School of Environment and Science, Nathan Campus, Griffith University, 170 Kessels Rd, Nathan, Brisbane, Queensland, AUSTRALIA. \\ 2Environmental Futures Research Institute, Griffith University, 170 Kessels Rd, Nathan, Brisbane, Queensland, AUSTRALIA
}

\begin{abstract}
Introduction: The recent development of extensively antibiotic resistant bacteria has necessitated the search for novel antibacterial compounds. An examination of aromatic plants and traditional medicines is an attractive option for drug discovery. Astrotrichia latifolia Benth. is a native Australia shrub that has yet to be tested for antibacterial activity. Methods: The ability of $A$. latifolia leaf extracts to inhibit the growth of a panel of bacterial pathogens was investigated by disc diffusion assay. Toxicity was examined using the Artemia franciscana nauplii bioassay. Results: A. latifolia leaf methanolic and aqueous extracts were completely ineffective at inhibiting the growth of gram-positive and gram-negative panels of bacteria. The extracts were non-toxic in the Artemia nauplii bioassay following $24 \mathrm{~h}$ exposure. Conclusion: A. latifolia leaf extracts were completely ineffective bacterial growth inhibitors. However, these extracts may have other therapeutic properties and testing against protozoa, virus and tumour cells
\end{abstract}

is required.

Key words: Araliaceae, Broad-leaf star hair, Antibacterial activity, Australian plant, Traditional medicine, Medicinal plants, Toxicity.

\section{Correspondence:}

Dr. Ian Edwin Cock

'School of Environment and Science, Nathan Campus, Griffith University, 170 Kessels Rd, Nathan, Brisbane, Queensland 4111, AUSTRALIA.

${ }^{2}$ Environmental Futures Research Institute, Griffith University, 170 Kessels Rd, Nathan, Brisbane, Queensland 4111, AUSTRALIA

Phone no: +61737357637

E-mail: I.Cock@griffith.edu.au

DOI: $10.5530 /$ pc.2021.1.9

\section{INTRODUCTION}

Traditional plant derived medicines have been used in most parts of the world for a variety of therapeutic purposes, including fighting microbial disease. Indeed, the ability of plant extracts to block the growth of pathogenic bacteria has become a focus of substantial recent study. ${ }^{1-5}$ Much of the research into traditional medicinal plant use has focused on Asian, ${ }^{6-8}$ African, ${ }^{9-11}$ Middle Eastern ${ }^{12-14}$ and South American ${ }^{15}$ plants. However, despite the potential of plants to provide us with useful pharmaceutical agents, the field is still relatively poorly studied. Only an estimated 5-10\% of the approximately 300,000-500,000 plant species worldwide have been screened for one or more bioactivities. ${ }^{9}$

The development of new antibiotic therapies is particularly urgent. The recent establishment of bacterial pathogens that are either extremely (XDR) or totally resistant (TDR) to common clinically used antibiotics ${ }^{16}$ has resulted in the need to develop new and effective antibiotic chemotherapies. There are now limited therapeutic options for many diseases caused by bacterial pathogens and the situation is expected to worsen in the future as bacteria exchange resistance genes. Indeed, the development of alternative antibacterial treatment modalities has become crucial and is considered by the World Health Organisation (WHO) to be one of the most serious challenges facing medical science. ${ }^{17}$ For reasons reviewed elsewhere ${ }^{16}$ it is unlikely that the previous methods of antibiotic discovery/development will be as successful in the future and new treatment modalities are urgently required. Traditional medicines and herbal remedies have great potential for antimicrobial drug development and there has recently been a substantial increase in interest in this field. ${ }^{18-32}$

Astrotricha lafifolia Benth. (synonym Astrotrichia floccosa var. Benth.; commonly known as broad-leaf star hair) is a shrub to $3 \mathrm{~m}$ that is native to eastern Australia. (Figure 1a). The dark green oblong-ovate leaves $(8-22 \mathrm{~cm}$ long by $2-8 \mathrm{~cm}$ wide; Figure $1 \mathrm{~b})$ have crisped margins and are bourne on a $2.5-8 \mathrm{~cm}$ petiole. We were unable to find records of medicinal use of this species in traditional Aboriginal healing systems. However, the first Australians did not have a written record of their traditional knowledge. Instead, they passed their traditions from one generation to the next by oral communication and it is likely that much of this knowledge has been lost as they adopted westernised medicine systems. Furthermore, in comparison to other regions of the world, relatively few studies have rigorously examined the antibacterial activity of Australian native plants, although there has recently been a substantial increase in interest in this field. ${ }^{18-32}$ This study was undertaken to screen A. lafifolia leaf extracts for the ability to inhibit the growth of a panel of gram-positive and gram-negative bacterial pathogens.

\section{MATERIALS AND METHODS}

\section{Plant material}

\section{Collection of plant material and extraction}

Astrotricha lafifolia Benth. leaves were obtained from and identified by Philip Cameron, senior botanic officer, Mt Cootha Botanical Gardens, Brisbane, Australia. The harvested leaves were washed in deionised water and processed within $4 \mathrm{hr}$ of collection. The leaves were dried in a Sunbeam food dehydrator and the dried material was ground to a coarse powder. Individual $1 \mathrm{~g}$ masses of the dried plant material was extracted extensively in $50 \mathrm{~mL}$ methanol (Ajax, AR grade) or deionised water for $24 \mathrm{hr}$ at $4^{\circ} \mathrm{C}$ with gentle shaking. The extract was filtered through filter paper (Whatman No. 54) under vacuum followed by drying by rotary evaporation. The resultant pellet was dissolved in $5 \mathrm{~mL}$ deionised water. The extract was passed through $0.22 \mu \mathrm{m}$ filter (Sarstedt) and stored at $4^{\circ} \mathrm{C}$.

\section{Qualitative phytochemical studies}

Phytochemical analyses of the A. latifolia leaf extracts for the presence of saponins, phenolic compounds, flavonoids, phytosteroids, triterpenoids, cardiac glycosides, anthraquinones, tannins and alkaloids were conducted by standard assays. ${ }^{33-35}$ 


\section{Antibacterial screening}

\section{Test micro-organisms}

All media was purchased from Oxoid Ltd., Australia. The reference strains of Escherichia coli (ATCC157293), Klebsiella pneumoniae (ATCC31488), Proteus mirabilis (ATCC21721) and Streptococcus pyogenes (ATCC19615) were purchased from American Tissue Culture Collection (ATCC), USA. Clinical isolate microbial strains of Aeromonas hydrophilia, Alcaligenes feacalis, Bacillus cereus, Citrobacter freundii, Pseudomonas aeruginosa, Pseudomonas fluorescens, Salmonella newport, Serratia marcescens, Staphylococcus aureus, Staphylococcus epidermidis and Yersinia entercolitica strains were obtained from Ms Michelle Mendell and Ms Jane Gifkins, Griffith University. All bacterial stock cultures were subcultured and maintained in nutrient broth at $4^{\circ} \mathrm{C}$.

\section{Evaluation of antimicrobial activity}

Antimicrobial activity of the A. latifolia leaf extracts was determined using a modified disc diffusion assay. ${ }^{36-39}$ Briefly, $100 \mu \mathrm{L}$ of each microbial suspension in log phase was spread onto individual nutrient agar plates and the extracts were tested for antimicrobial activity using $5 \mathrm{~mm}$ sterilised filter paper discs. The discs were each infused with $10 \mu \mathrm{L}$ of the individual plant extract, allowed to dry and placed onto the inoculated

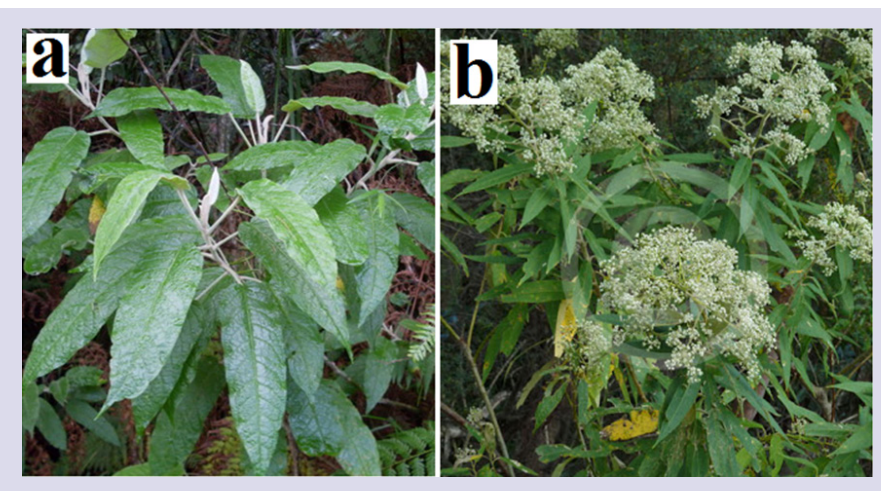

Figure 1: A. lafifolia (a) leaves and (b) flowers.

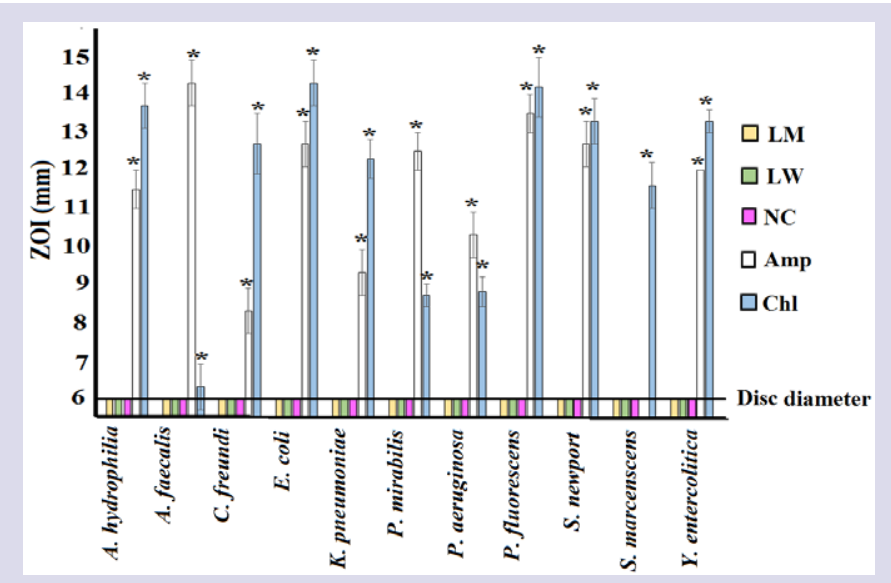

Figure 2: Growth inhibitory activity of $A$. latifolia leaf extracts and reference antibiotics against gram-negative bacterial species measured as ZOIs (mm) \pm SEM. $L=$ leaf; $M=$ methanolic extract; $W=$ aqueous extract; Amp = ampicillin $(10 \mu \mathrm{g}) ; \mathrm{Chl}=$ chloramphenicol $(10 \mu \mathrm{g}) ; \mathrm{NC}$ $=$ negative control. All assays were completed three times, each with internal triplicates $(n=9)$ and the results are expressed as mean zones of inhibition $(\mathrm{mm}) \pm \mathrm{SEM}$. plates. The plates were allowed to stand at $4^{\circ} \mathrm{C}$ for $2 \mathrm{hr}$ before incubation at $37^{\circ} \mathrm{C}$ for $24 \mathrm{hr}$. The diameters of the zones of inhibition (ZOIs) were measured to the closest whole millimetre. Each assay was performed three times in triplicate $(n=9)$. Mean values $( \pm$ SEM) are reported in this study. Standard discs of ampicillin $(10 \mu \mathrm{g})$ and chloramphenicol $(10 \mu \mathrm{g})$ were obtained from Oxoid, Australia and were used as positive controls to compare antibacterial activity. Filter discs infused with $10 \mu \mathrm{L}$ of distilled water were used as a negative control.

\section{Artemia franciscana nauplii toxicity screening}

Toxicity was tested using an adapted Artemia franciscana nauplii lethality assay. ${ }^{40-42}$ Briefly, A. franciscana nauplii were incubated in the presence of the extracts, reference toxin $(1 \mathrm{mg} / \mathrm{mL}$ potassium dichromate) or artificial seawater (negative control) at $25 \pm 1{ }^{\circ} \mathrm{C}$ under artificial light. All treatments were performed three times in triplicate $(n=9)$. The number of dead were counted in each well at $24 \mathrm{hr}, 48 \mathrm{hr}$ and $72 \mathrm{hr}$. At the completion of the $72 \mathrm{hr}$ exposure period, the remaining live nauplii were sacrificed and the total number of nauplii in each well were counted and used to calculate the $\%$ mortality per well. $\mathrm{LC}_{50}$ values were calculated for each treatment using probit analysis.

\section{Statistical analysis}

Data are expressed as the mean \pm SEM of three independent experiments with internal triplicates $(n=9)$. One-way ANOVA was used to calculate statistical significance between control and treated groups, with a $P$ value $<0.01$ considered to be statistically significant.

\section{RESULTS}

\section{Liquid extraction yields and qualitative phytochemical screening}

Extraction of $1 \mathrm{~g}$ of dried and powdered A. latifolia leaf with methanol and water yielded 320 and $218 \mathrm{mg}$ of extracted material respectively (Table 1). Methanol was a better extractant, resulting in higher yield of extracted material compared to water. The extracts were resuspended in $10 \mathrm{~mL}$ of deionised water (containing 1\% DMSO), resulting in the extract concentrations shown in Table 1. Qualitative phytochemical studies showed that both extracts had similar phytochemical profiles. Both contained high levels of phenolic compounds and flavonoids, as well as moderate levels of tannins and low levels of saponins and triterpenoids.

\section{Antimicrobial activity}

To determine the growth inhibitory activity of the A. lafifolia leaf extracts, aliquots $(10 \mu \mathrm{L})$ of each extract were screened in the disc diffusion assay. The A. latifolia leaf extracts were ineffective at inhibiting the growth of all gram-negative (Figure 2) and gram positive (Figure 3) bacterial species tested. In contrast, both positive control antibiotics (ampicillin and chloramphenicol) were effective growth inhibitors, with ZOI's of up to $14.3 \mathrm{~mm}$ (chloramphenicol against $E$. coli). We were therefore unable to determine the MIC values for any extract as they were completely ineffective at all concentrations tested.

\section{Quantification of Toxicity}

The toxicity of the A. latifolia leaf extracts was initially tested at $1000 \mu \mathrm{g} /$ $\mathrm{mL}$ in the A. franciscana nauplii bioassay (Figure 4 ). The mortality in the presence of all extracts was substantially $<50 \%$ at $24 \mathrm{~h}$ when $1000 \mu \mathrm{g} / \mathrm{mL}$ concentrations were tested. Thus, the methanolic and water extracts were deemed to be non-toxic. Extracts with $24 \mathrm{~h} \mathrm{LC}_{50}$ values $>1000 \mu \mathrm{g} / \mathrm{mL}$ have previously been defined as non-toxic. ${ }^{40-42}$ In contrast, the potassium dichromate positive control induced substantial mortality within $4 \mathrm{~h}$ (results not shown), with $100 \%$ mortality induction seen by $24 \mathrm{~h}$. The 
Table 1: The mass of dried extracted material, the concentration after resuspension in deionised water and qualitative phytochemical screenings of the A. latifolia leaf extracts.

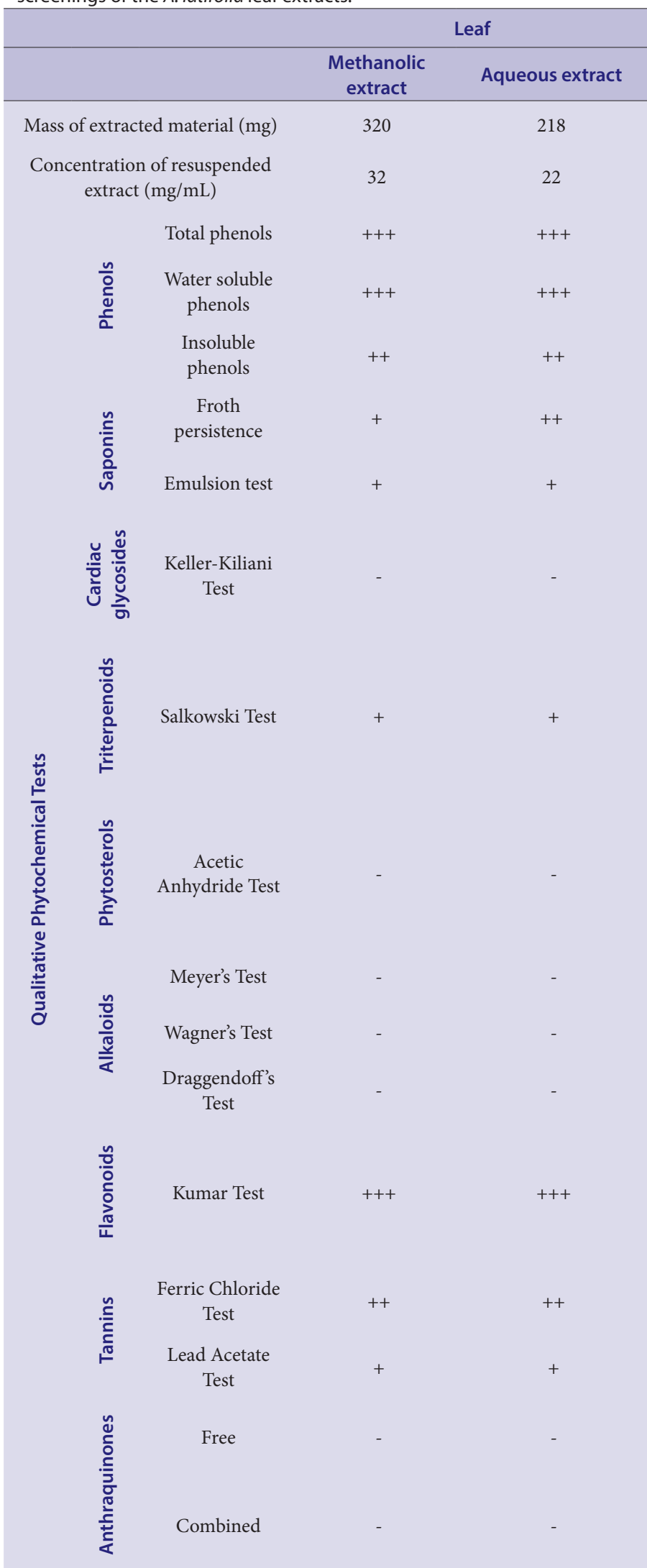

+++ indicates a large response; ++ indicates a moderate response; + indicates a minor response; - indicates no response in the assay.

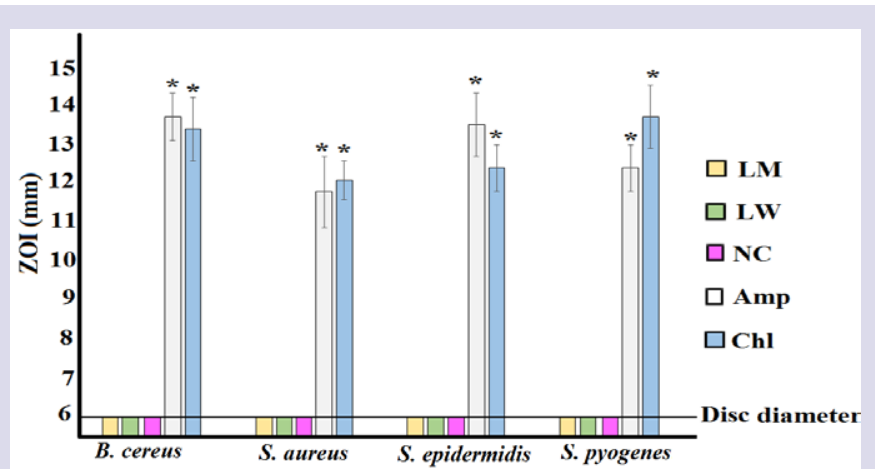

Figure 3: Growth inhibitory activity of $A$. latifolia leaf extracts and reference antibiotics against gram-positive bacterial species measured as ZOIs $(\mathrm{mm}) \pm \mathrm{SEM}$. L = leaf; $\mathrm{W}=$ aqueous extract; $\mathrm{Amp}=$ ampicillin $(10 \mu \mathrm{g}) ; \mathrm{Chl}=$ chloramphenicol $(10 \mu \mathrm{g}) ; \mathrm{NC}=$ negative control. All assays were completed three times, each with internal triplicates $(n=9)$ and the results are expressed as mean zones of inhibition $(\mathrm{mm}) \pm$ SEM.

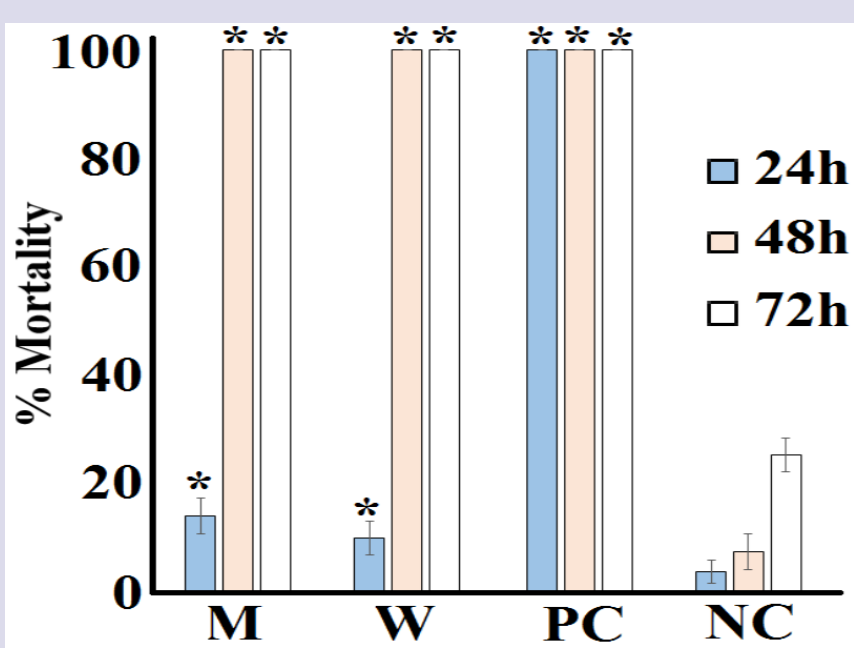

Figure 4: The lethality of the $A$. latifolia leaf extracts, potassium dichromate control (PC; $1000 \mu \mathrm{g} / \mathrm{mL}$ ) and seawater negative control (NC) following 24,48 and $72 \mathrm{hr}$ of exposure. $\mathrm{M}=$ methamolic extract; $\mathrm{W}=$ aqueous extract. All bioassays were performed three times in triplicate $(n=9)$ and are expressed as mean \pm SEM. * indicates results that are significantly different to the untreated (seawater) control at the equivalent exposure time $(P<0.01)$

mortality increased following exposure to the A. latifolia leaf extracts at $48 \mathrm{~h}$ and was further increased following $72 \mathrm{hr}$ exposure.

\section{DISCUSSION}

The development of new antibiotic chemotherapies is a high priority for medical science due to the recent development of large numbers of antibiotic resistant bacterial strains. ${ }^{16,17} \mathrm{~A}$ parallel decrease in the discovery of new antibiotic medicines by conventional strategies has increased interest in re-evaluating medicinal plants for new antibiotic chemotherapies. ${ }^{16}$ Whilst we were unable to find reports of the traditional use of A. latifolia medicinally, the first Australians did not have a written record of their traditional knowledge and instead passed their traditions from one generation to the next by oral communication. It therefore is likely that much of their traditional knowledge has been lost as they adopted westernised medicine systems. It is therefore possible that 
some first Australian groups may have had ethnobotanical uses for this species that are no longer widely known and screening of this species for antibacterial activity is warranted. Notably, the A. latifolia extracts completely lacked inhibitory activity against all bacterial species tested.

A single assay technique was used to screen for antibacterial activity in this study. We chose to use the disc diffusion assay as it is a rapid method and it has previously been widely utilised in other studies. Therefore, comparisons between studies are relatively simple. However, as the disc diffusion method is reliant on the diffusion of a molecule through the aqueous environment of an agar gel, this assay may be affected by the solubility of the extract compounds in the aqueous environment. Polar compounds that are highly soluble in water would be expected to diffuse easily in the gel, whereas less soluble compounds would not diffuse as readily and thus be concentrated around the disc. Diffusion of molecules within an agar gel is also affected by the size of the molecules. The movement of large, complex phytochemicals (e.g. tannins, triterpenoids) through agar gels by diffusion would also be retarded and may provide a false idea of the efficacy of an extract. As many tannins and triterpenoids have well described antibiotic properties, screening for growth inhibition using agar diffusion techniques may give a fallacious view of its inhibitory potential. For this reason, whilst this is a handy assay for screening aqueous extracts, this technique may not be ideal for nonpolar compounds. For examining nonpolar mixtures, other techniques such as liquid dilution assays may be preferred. Liquid dilution studies may have been better suited to screen A. latifolia leaf extracts for activity and future studies will use these techniques to re-examine the extracts for antibacterial activity.

The findings reported here also indicate that the extracts examined were non-toxic $\left(24 \mathrm{hr} \mathrm{LC} \mathrm{LC}_{50}>1000 \mu \mathrm{g} / \mathrm{mL}\right)$ in the Artemia nauplii bioassay. Whilst toxicity was assessed in this study with the test organism $A$. franciscana, toxicity towards $A$. franciscana has previously been shown to correlate well with toxicity towards human cells for many toxins. ${ }^{40-42}$ However, further studies are required to determine whether this is also true for the A. latifolia leaf extracts examined in these studies.

\section{CONCLUSION}

Methanolic and aqueous A. latifolia leaf extracts displayed no antibacterial activity in the disc diffusion assay. The extracts were nontoxic towards Artemia nauplii.

\section{ACKNOWLEDGEMENT}

The authors are grateful to Michelle Mendell and Jane Gifkins of Griffith University for providing the clinical bacterial strains and to Phillip Cameron of the Brisbane Botanical Gardens for providing the plant material used in this study. Financial support for this work was provided by the Environmental Futures Research Institute, Griffith University, Australia.

\section{CONFLICT OF INTEREST}

The authors report no conflicts of interest.

\section{ABBREVIATIONS}

DMSO: Dimethyl sulfoxide; $\mathbf{L C}_{50}$ : The concentration required to achieve 50\% mortality; MIC: Minimum inhibitory concentration; ZOI: Zone of inhibition.

\section{REFERENCES}

1. Kamboj VP. Herbal medicine. Curr Sci. 2000;78(1):35-9.

2. Hostettmann K, Hamburger M. Search for new lead compounds of natural origin. In Perspectives in Medical Chemistry. Verlag Helvitica Acta, Basel. 1993.
3. Wright MH, Sirdaarta J, White A, et al. GC-MS headspace analysis of Terminalia ferdinandiana fruit and leaf extracts which inhibit Bacillus anthracis growth. Pharmacog J. 2017;9(1):73-82. DOI: 10.5530/pj.2017.1.14

4. Mpala LN, Chikowe GR, Cock IE. Growth inhibitory properties of extracts prepared from selected Leptospermum and Melaleuca species against a panel of pathogenic bacteria. Pharmacog Commn. 2016;6(4):215-24. DOI: 10.5530/ pc. 2016.4.4

5. Omer E, Elshamy Al, Nassar M, et al. Plantago squarrosa Murray extracts inhibit the growth of some bacterial triggers of autoimmune diseases: GC-MS analysis of an inhibitory extract. Inflammopharmacol. 2018;27(2):373-85. DOI: 10.1007/ s10787-018-0547-0

6. Newman DJ, Cragg GM, Snader KM. The influence of natural products on drug discovery. Nat Prod Rep. 2000;17(3):215-34.

7. Gaillot C, Sirdaarta J, Cock IE. Examination of the antimicrobial and anticancer properties of mangosteen. Acta Hortic. 2016;1106:231-8.

8. Wright $\mathrm{MH}$, Greene AC, Cock IE. Investigating the pharmacognostic potential of Indian Terminalia spp. in the treatment and prevention of yersiniosis. Pharmacog Commn. 2017;7(3):108-13. DOI: 10.5530/pc.2017.3.16

9. Gilani AH, Atta-ur-Rahman. Trends in ethnopharmacology. J Ethnopharmacol. 2005; 100(1-2):43-9

10. Hübsch Z, Zyl RLV, Cock IE, et al. Interactive antimicrobial and toxicity profiles of conventional antimicrobials with Southern African medicinal plants. South African Journal of Botany. 2014;93:185-97. DOI: 10.1016/j.sajb.2014.04.005

11. Cock IE, Vuuren SFV. Anti-Proteus activity of some South African medicinal plants: Their potential for the treatment and prevention of rheumatoid arthritis. Inflammopharmacol. 2014;22(1):23-36. DOI 10.1007/s10787-013-0179-3.

12. Omer E, Elshamy A, EIGendy AN, et al. Cakile maritima Scop. Extracts inhibit the growth of some bacterial triggers of autoimmune diseases: GC-MS analysis of an inhibitory extract. Pharmacog J. 2016;8(4):361-74. DOI: 10.5530/pj.2016.4.9

13. Biggs I, Sirdaarta J, White A, et al. GC-MS analysis of Commiphora molmol oleo-resin extracts which inhibit the growth of bacterial triggers of selected autoimmune diseases. Pharmacog J. 2016;8(3):191-202. DOI: 10.5530/ pj.2016.3.4

14. Biggs I, Sirdaarta J, White A, et al. GC-MS analysis of frankincense extracts which inhibit the growth of bacterial triggers of selected autoimmune diseases. Pharmacog Commn. 2016;6(1):10-22. DOI: 10.5530/pc.2016.1.3

15. Mohanty S, Cock IE. Evaluation of the antibacterial activity and toxicity of Myrciaria caulifloria methanolic leaf and fruit extracts. Int J Microbiol. 2009;7(2).

16. Cheesman MJ, llanko A, Blonk B, et al. Developing new antimicrobial therapies: Are synergistic combinations of plant extracts/compounds with conventional antibiotics the solution?. Pharmacog Rev. 2017;11(2):57-72. DOI: 10.4103/phrev. phrev_21_17

17. WHO. Antimicrobial Resistance. World Health Organization. 2016. Available from: http://www.who.int/mediacentre/factsheets/fs194/en/. [Cited on 2019 May 10].

18. Sirdaarta J, Matthews B, Cock IE. Kakadu plum fruit extracts inhibit the growth of the bacterial triggers of rheumatoid arthritis: Identification of stilbene and tannin components. J Funct Food. 2015;17:610-20. DOI: 10.1016/j.jff.2015.06.019

19. Ilanko A, Cock IE. The interactive antimicrobial activity of contentional antibiotics and Petalostigma spp. extracts against bacterial triggers of some autoimmune inflammatory diseases. Pharmacogn J. 2019;11(2):292-309. DOI: 10.5530/ pj.2019.11.45

20. Winnett $\mathrm{V}$, Sirdaarta J, White A, et al. Inhibition of Klebsiella pneumonia growth by selected Australian plants: Natural approaches for the prevention and management of ankylosing spondylitis. Inflammopharmacol. 2017;25(2):22335. DOI: 10.1007/s10787-017-0328-1

21. Cheesman $M$, White $A$, Matthews $B$, et al. Terminalia ferdinandiana fruit and leaf extracts inhibit methicillin-resistant Staphylococcus aureus growth. Planta Medica. 2019;85(16):1253-62. DOI: 10.1055/a-1013-0434

22. Cock IE, Vuuren V. The traditional use of southern African medicinal plants for the treatment of bacterial respiratory diseases: A review of the ethnobotany and scientific evaluations. J Ethnopharmacol. 2020. DOI: 10.1016/j.jep.2020.113204

23. Courtney R, Sirdaarta J, Matthews B, et al. Tannin components and inhibitory activity of Kakadu plum leaf extracts against microbial triggers of autoimmune inflammatory diseases. Pharmacogn J. 2015;7(1):18-31. DOI: 10.5530/ pj.2015.7.2

24. Wright $\mathrm{MH}$, Sirdaarta J, Matthews B et al. Growth inhibitory activity of Kakadu plum extracts against the opportunistic pathogen Clostridium perfringens: New leads in the prevention and treatment of clostridial myonecrosis. Pharmacogn J. 2016;8(2):144-54. DOI: 10.5530/pj.2016.2.8

25. Tiwana G, Cock IE, White A, et al. Use of specific combinations of the triphala plant component extracts to potentiate the inhibition of gastrointestinal bacterial growth. J Ethnopharmacol. 2020;112937. DOI: 10.1016/j.jep.2020.

26. Mandeville A, Cock IE. Terminalia chebula Retz. fruit extracts inhibit bacterial triggers of some autoimmune diseases and potentiate the activity of tetracycline. Indian J Microbiol. 2018;58(4):496-506. DOI: 10.1007/s12088-0180754-9

27. Arkhipov A, Sirdaarta J, Rayan $\mathrm{P}$, et al. An examination of the antibacterial, antifungal, anti-Giardial and anticancer properties of Kigelia africana fruit 
extracts. Pharmacogn Commun. 2014;4(3):62-76. DOI: 10.5530/pc.2014.3.7

28. Ilanko $\mathrm{P}$, McDonnell PA, Vuuren SFV, et al. Interactive antibacterial profile of Moringa oleifera Lam. Extracts and conventional antibiotics against bacterial triggers of some autoimmune inflammatory diseases. S Afr J Bot. 2019;124:420-35.

29. Lee CJ, Wright MH, Arnold MSJ, et al. Inhibition of Streptococcus pyogenes growth by native Australian plants: New approaches towards the management of impetigo, pharyngitis and rheumatic heart disease. Pharmacogn Commun. 2016;6(3):164-73. DOI: 10.5530/pc.2016.3.6

30. Wright MH, Sirdaarta J, White A, et al. GC-MS headspace analysis of Terminalia ferdinandiana fruit and leaf extracts which inhibit Bacillus anthracis growth. Pharmacogn J. 2017;9(1):73-82. DOI: 10.5530/pj.2017.1.14

31. McManus $\mathrm{K}$, Wood $\mathrm{A}$, Wright $\mathrm{MH}$, et al. Terminalia ferdinandiana Exell. extracts inhibit the growth of body odour-forming bacteria. Internat J Cosmetic Sci. 2017;39(5):500-10. DOI: 10.1111/ics.12403

32. Hutchings A, Cock IE. An interactive antimicrobial activity of Embelica officinalis Gaertn. Fruit extracts and conventional antibiotics against some bacteria triggers of autoimmune inflammatory diseases. Pharmacogn J. 2018;10(4):65462. DOI: $10.5530 /$ pj.2018.4.108

33. Wright $\mathrm{MH}$, Matthews $\mathrm{B}$, Arnold MSJ, et al. The prevention of fish spoilage by high antioxidant Australian culinary plants: Shewanella putrefaciens growth inhibition. Internat J Food SciTechnol. 2016;51(3):801-13. DOI: 10.1111/ijfs.13026

34. Rayan P, Matthews $B$, McDonnell PA, et al. Terminalia ferdinandiana extracts as inhibitors of Giardia duodenalis proliferation: A new treatment for giardiasis. Parasitol Res. 2015;114(7):2611-20. DOI: 10.1007/s00436-015-4465-4

35. Noé W, Murhekar S, White A, et al. Inhibition of the growth of human dermatophytic pathogens by selected Australian and Asian plants traditionally used to treat fungal infections. Journal de Mycologie Médicale. 2019;29(4):33144. DOI: 10.1016/j.mycmed.2019.05.003

36. Wright MH, Sirdaarta J, White A, et al. GC-MS headspace analysis of Terminalia ferdinandiana fruit and leaf extracts which inhibit Bacillus anthracis growth. Pharmacogn J. 2017;9(1):73-82. DOI: 10.5530/pj.2017.1.14

37. Cock IE, Wright MH, Matthews $B$, et al. Bioactive compounds sourced from Terminalia spp. in bacterial malodour prevention: An effective alternative to chemical additives. Internat J Cosmetic Sci. 2019;41(5):496-508. DOI: 10.1111/ ics. 12567

38. Hutchings A, Cock IE. An interactive antimicrobial activity of Embelica officinalis Gaertn. Fruit extracts and conventional antibiotics against some bacterial triggers of autoimmune inflammatory diseases. Pharmacogn J. 2018;10(4):65462. DOI: $10.5530 /$ pj.2018.4.108

39. Rabadeaux C, Vallette L, Sirdaarta J, et al. An examination of the antimicrobial and anticancer properties of Khaya senegalensis (Desr). A Juss. bark extracts. Pharmacogn J. 2017;9(4):504-18. DOI: 10.5530/pj.2017.4.82

40. Cock IE, Ruebhart DR. Comparison of the brine shrimp nauplii bioassay and the ToxScreen-II test for the detection of toxicity associated with Aloe vera (Aloe barbadensis Miller) leaf extract. Pharmacogn Res. 2009;1(2):98-101.

41. Shalom J, Cock IE. Terminalia ferdinandiana Exell. fruit and leaf extracts inhibit proliferation and induce apoptosis in selected human cancer cell lines. Nutrit Cancer. 2018;70(4):579-93. DOI: 10.1080/01635581.2018.1460680

42. Wright MH, Shalom J, Matthews B, et al. Terminalia ferdinandiana Exell. extracts inhibit Shewanella spp. growth and prevent fish spoilage. Food Microbiol. 2019:78:114-22. DOI: 10.1016/j.fm.2018.10.006

\section{PICTORIAL ABSTRACT}

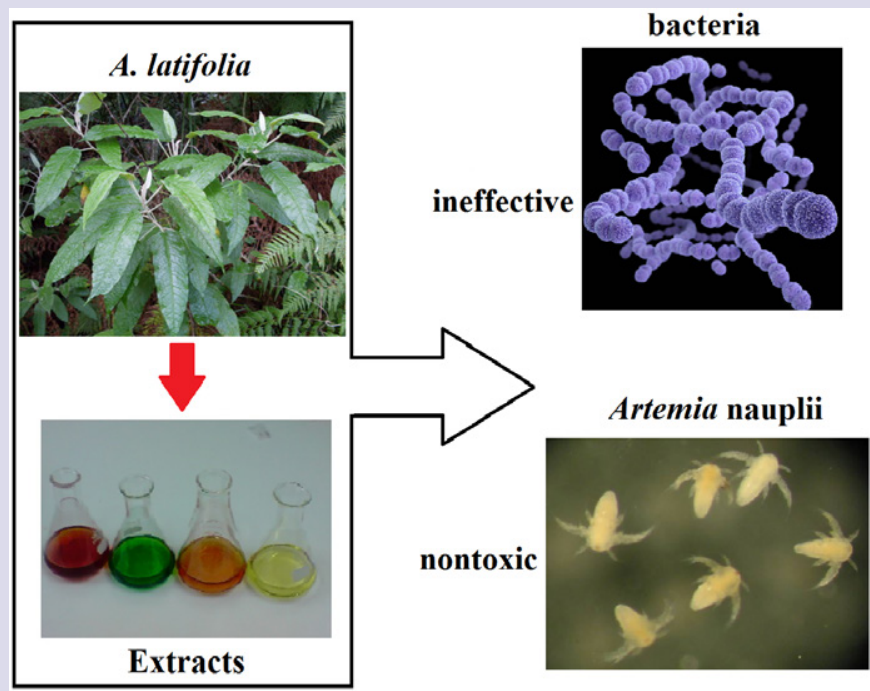

\section{SUMMARY}

- A. latifolia leaf extracts were screened for the ability to block the growth of a panel of human bacterial pathogens.

- No inhibitory activity was evident against any of the bacterial species tested.

- Toxicity of the $A$. latifolia leaf extracts was determined using the Artemia nauplii toxicity bioassay.

- $\quad$ Both the methanolic and aqueous extracts were non-toxic.

\section{ABOUT AUTHORS}

Ms Lindiwe Mpala completed BSc at Griffith University in Life Sciences. Following graduation, she undertook a research project in Dr. lan Cock's laboratory in the School of Natural Sciences at Griffith University. The project examined the growth inhibitory properties of a variety of Australian native plants against an extensive panel of bacterial pathogens.

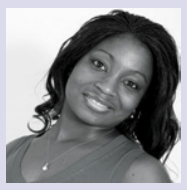

Ms. Getmore Chikowe completed BSc at Griffith University in Life Sciences. Following graduation, she undertook a research project in Dr. lan Cock's laboratory in the School of Natural Sciences at Griffith University. The project examined the growth inhibitory properties of a variety of Australian native plants against an extensive panel of bacterial pathogens.

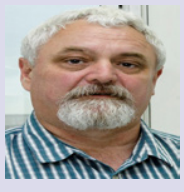

Dr. Ian Cock leads a research team in the Environmental Futures Research Institute and the School of Natural Sciences at Griffith University, Australia. His research involves bioactivity and phytochemical studies into a variety of plant species of both Australian and international origin, including Aloe vera, South Asian and South American tropical fruits, as well as Australia plants including Scaevola spinescens, Pittosporum phylliraeoides, Terminalia ferdinandiana (Kakadu plum), Australian Acacias, Syzygiums, Petalostigmas and Xanthorrhoea johnsonii (grass trees). This range of projects has resulted in nearly 200 publications in a variety of peer reviewed journals. 